\title{
The Making of a Soviet Diplomat
}

Ivan Mikhailovich Lyakhovetsky was born on 7 January 1884 in the ancient Russian town of Kirillov, near Nizhny-Novgorod, in the comfortable environment of a nobleman's castle, where his father was a tutor to the son of the family. Maisky (Man of May), was a nom de plume he assumed in 1909 while in exile in Germany. His childhood was spent in Siberia, in Omsk, where his father, having studied medicine in St Petersburg, served as a medical officer. ${ }^{1}$ His father was of Jewish Polish descent, a fact which Maisky preferred to conceal. In his enchanting childhood memoirs he went a long way to stress the atheist atmosphere at home, but made the point that 'officially, of course, we were considered to be Orthodox ... as a schoolboy I was obliged to learn the catechism in class, to attend Vespers on Saturdays and Mass on Sundays, and to go to confession without fail before Easter'. Maisky, though, would find it difficult to shake off the 'Jewish image'. Both in England and in the Soviet Union he was often perceived to be Jewish. The nephew of the famous Russian historian, Evgeny Tarle, recalled that his aunt, who 'had a nose for Jews who'd been promoted at the time of the proletarian revolution', confided in him that she thought 'Maisky wasn't really called Maisky, let alone "Ivan Mikhailovich": "Isaak Moiseevich", more likely'. Victor Gollancz, the Jewish leftist publisher, remembered Maisky telling 'wonderful Jewish stories, which he called Armenian, and loved listening to mine, which he called Armenian too'. ${ }^{2}$

His father's 'secret love' and the 'mainspring of his soul' was the 'passion for science'. He served as a formidable role model for Maisky and as a source of inspiration for an insatiable intellectual aptitude and curiosity, professional dedication and unbridled ambition. His father's rigidity and somewhat reserved nature were cushioned by Maisky's mother, Nadezhda Ivanovna (née Davydova), who was a village teacher with a strong literary and artistic proclivity. In his memoirs, Maisky depicts her fondly as being 'of a choleric temperament - lively, inconsistent, quick-tempered and talkative ... She had something unique in herself, a kind of charm, which attracted people to her and easily made her the centre of attention.'

Maisky was exposed to literature from an early age. The packed bookshelves at home housed beautifully bound collected works of Shakespeare, Byron and Schiller, as well as the writing of the more radical intelligentsia such as Nekrasov, Dobrolyubov, Herzen and Pisarev. Maisky was well aware of the debate raging at the time on the purpose of literature and art, and on realism and aestheticism. Though claiming in later years, for obvious reasons, to have sided with the 'utilitarians', the young Ivan uncritically devoured 'stacks of books and periodicals'. He was particularly captivated by Heine, his 


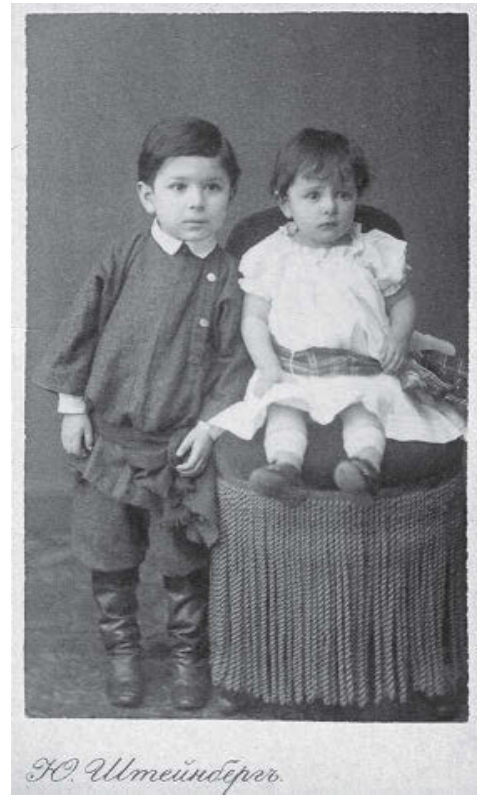

9. Jan Lyakhovetsky (Maisky) with his younger sister.

lifetime compass and companion, whose portrait was to hang over his desk. Barely sixteen years of age, he expressed this admiration in a letter to Elizaveta, his confidante cousin:

I have never seen a finer face than Heine's. Every day I discover more and more excellence in Heine and I am convinced that his perpetually satirical, perpetually sceptical Aristophanes of the nineteenth century is one of the greatest geniuses and judges of the human soul in general, and of the people of our times in particular. Heine is humanity. He personifies it to perfection as nobody else has done. In him is reflected all the good and bad in humanity, the wide and motley panorama of the human marketplace, all its suffering and sorrow, all its anger and indignation. ${ }^{3}$

The literary atmosphere at home refined Maisky's acute powers of observation, which were enhanced by his rich imagination and his curiosity. It helped forge his complex personality, which, while romantic and artistic, was also governed by a belief in 'reason, science, knowledge, and the right of man to be master of life on earth'. ${ }^{4}$ The novels opened a window on Europe and awakened in Maisky a longing for travel and an interest in geography which would gradually shape his cosmopolitan outlook once in exile. That particular inquisitiveness was enriched by exposure to the bustling life of Omsk's port, where Maisky spent any free moment he had strolling about the wharves and by the steamers, 'looking at everything, listening and nosing about ... I listened 
to the stories of the pilots and sailors about their work and adventures and about the distant towns and places they visited. ${ }^{5}$

In reconstructing a revolutionary past, Maisky would later identify a rebellious streak in the family - a dissident member of the clergy who went off the rails and joined certain revolutionary circles in the mid-nineteenth century. Likewise he would claim that his own parents sympathized with the Populist movement, that his mother had even 'gone down to the people', and that his father had come into conflict with the authorities at the hospital he worked in over his failure to prevent the young medical cadets from expressing revolutionary ideas in 1905. He makes much of the special relationship he cultivated with his artist uncle, M.M. Chemodanov, who worked as a zemstvo doctor in a remote village and was mildly involved in revolutionary activities. However, at its core, Maisky's background and education were typical of the professional middle class, devoid of any political awareness. ${ }^{6}$

Having graduated from the local gymnasium (grammar school) at the age of 17 with a gold medal, Maisky enrolled at St Petersburg University, where he read history and philology. His literary talents were noticed around that time, when his first poem, 'I Wish to Be a Great Thunderstorm', was published in Siberian Life under the pseudonym 'New Man'. His university education at St Petersburg, however, came to an abrupt and premature end when he was arrested and charged with revolutionary agitation. ${ }^{7} \mathrm{He}$ was put under police surveillance in Omsk, where he joined the Menshevik wing of the Russian Social Democratic Movement. In 1906 he was detained once again for taking an active part in the 1905 revolution, and was sentenced to exile in Tobolsk, where he produced a manuscript inspired by Sidney and Beatrice Webb and their History of Trade Unionism. Maisky had stumbled upon this by sheer chance when he was a student in St Petersburg. He would later confess to the Webbs that it 'greatly contributed to my political education and to a certain extent helped me to find the path which I followed in my subsequent life'. 'Never indeed,' he wrote to his cousin in 1901, 'have I read any novel with such a thrill as the Webbs' book! How feeble, miserable and nonsensical all

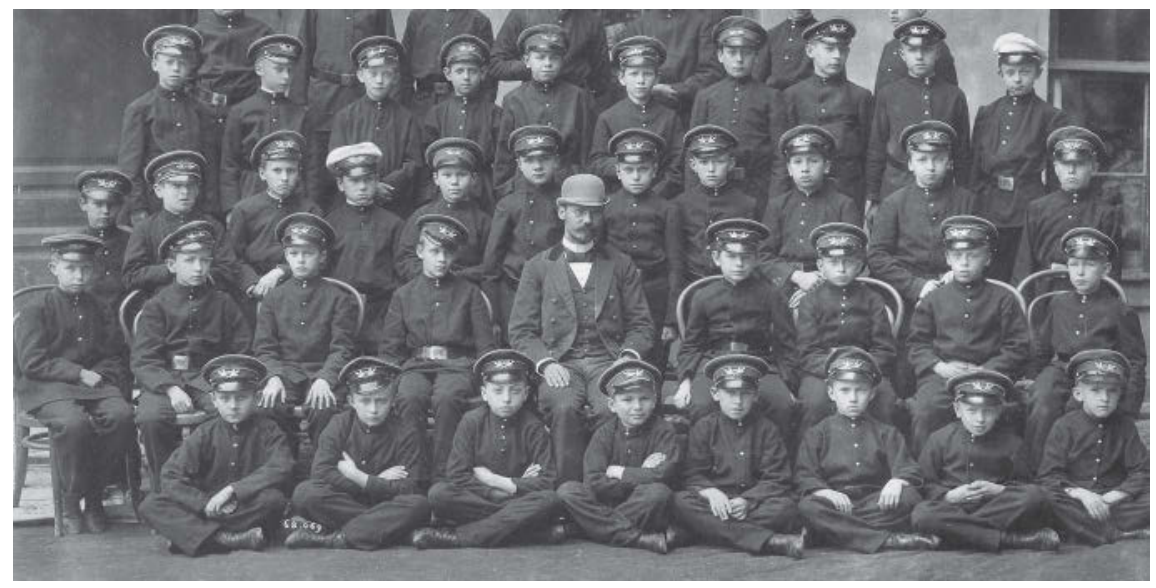

10. A model pupil in the gymnasium (front row, fifth from the right). 


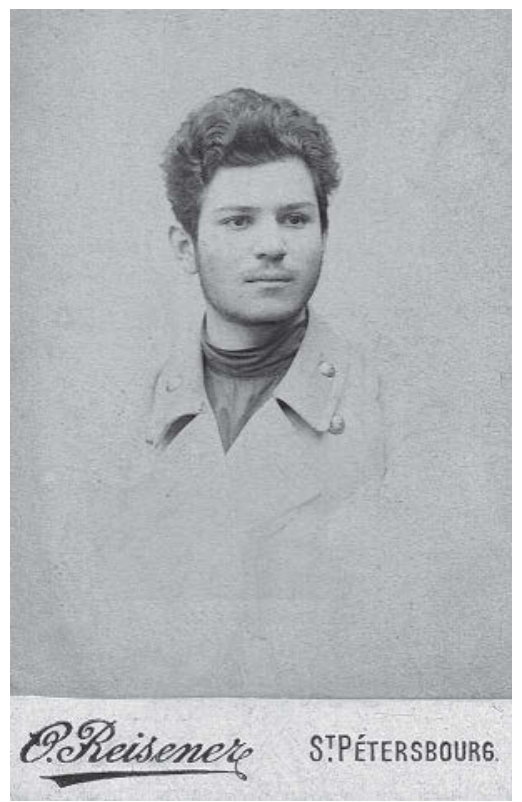

11. The breeding of a revolutionary: Maisky as a student at St Petersburg University.

my former literary enthusiasms seem to me!'8 The evolutionary Fabian stream, with its strong social-humanist bent, suited Maisky's temperament and served him as a political beam of light. Its residue was always close to the surface, even when he had to break with his Menshevik past and display loyalty to Bolshevism. Once in England, he cultivated intimate relations with the Webbs which lasted until their death, as is well attested in both his and Beatrice Webb's diaries.

Maisky's sentence was eventually commuted to exile abroad. In his memoirs, written under the cloud of the purges in the wake of the Ribbentrop-Molotov Pact (when his stock was low in Moscow), Maisky claims that his desire to emigrate was driven by a wish to study 'socialism and the European workers' movement'. However, the attraction of exile seems to have been more profound, revealing a cosmopolitan streak and a prodigious curiosity which can be traced back to his childhood, when he used to accompany his father - who believed that 'nothing develops a child so much as travel and getting to know new places, new people, new races and customs' - on his distant missions across Siberia. When the family moved to St Petersburg for a year, we find the nine-year-old Ivan still fascinated, 'standing a long while on the granite quays of the Neva, watching the complicated manoeuvres of the Finnish boats, the loading of foreign ships, the tiny Finnish steamers darting briskly in all directions like dark blue beetles'. His exile further enhanced an enduring admiration for European (particularly German) culture, as he openly confessed in a letter to his mother: 'I am still extremely happy with being abroad. I feel that I am growing quickly and powerfully here, in mind and in spirit. And, in fact, I'm almost grateful to the circumstances which have forced 
me to quit Russian soil. ${ }^{\prime 9}$ 'I like travel,' he confessed to Bernard Shaw years later, 'and I have travelled much over Europe and Asia ... When I see people boarding a train, a ship or a plane, I feel a sort of romantic glow. ${ }^{\prime 10}$

After a brief stay in Switzerland, Maisky settled in Munich, then the hub for Russian immigrants and artists, notably Kandinsky and his circle. Though associated with the Russian revolutionary movement, Maisky was as much involved in the activities of the German Social Democratic Party and the trade unions. He obtained his Master's degree in economics at Munich University, and was well on with his doctoral dissertation when the gathering clouds of war led to an unanticipated and fateful new emigration - to London. The nomadic life suited his nature:

After Germany, it'll be very good to get acquainted with life and people in the United Kingdom, and ultimately I don't mind where I live: Munich or London. On the way to England I'll stop off for a week in Paris, to have a look at the city ... And then I'll head on from there to the British capital. I go to new countries with great interest and great expectations; we'll see whether the latter come true. Ultimately, I think the main charm in life is a constant change of impressions, and nothing aids that so much as travel, rapid movement from one place to another. ${ }^{11}$

However, Maisky's first encounter with London in November 1912, rather belied his later fascination with England. His Russian upbringing and life in the German socialist milieu did not predispose him to the kind of blind admiration for British liberalism that seized many of the romantic exiles of the nineteenth century. London, he felt, 'swallowed and suffocated' him. He did not know the language and felt lost in that 'giant stone ocean' ${ }^{12}$ Indeed, those early gloomy impressions are evident in a letter to his mother:

Of course, I find London very interesting - from the political and socio-economic points of view - and I'm not at all sorry that I'm spending the current winter here. But I wouldn't want to stop in these parts too long. Just the thought of getting stuck here permanently brings on a freezing ennui. No, I definitely don't like London! It's huge, dark, dirty, uncomfortable, with boring rows of identical little houses, permanently shrouded in fog ... You don't see the sun here for weeks, and that's terribly depressing. I now understand why spleen is called the English disease, and I also understand why Heine so disliked the country of the proud Britons. 'The ocean would have swallowed England long ago,' he once commented, 'if it weren't afraid of an upset stomach.' And he wasn't far wrong: to digest a 'nut' like England wouldn't be that easy. ${ }^{13}$

And yet the years in London and his friendship with Georgii Vasilevich Chicherin and Maksim Maksimovich Litvinov (who, for two decades, as commissars for foreign affairs, were to steer Soviet foreign policy) were to have a profound impact on Maisky's later career. The three were brought together by Litvinov's future wife, Ivy, who was born in London, the product of an implausible union between a Jewish intellectual and an Indian army colonel's daughter. A non-conformist writer and rebel, she found solace from her 
despised employment (with an insurance firm) at the Golders Green home of her aunt and uncle, the Eders, who were left-wing thinkers. They held lively intellectual soirées, with revolutionaries, Freudians, Fabians and literary figures such as Bernard Shaw and H.G. Wells. ${ }^{14}$ It was at the Eders' house that Maisky, a frequent visitor, cemented his friendship with Litvinov and Chicherin. ${ }^{15}$

The three lived just around the corner from each other, first in Golders Green and then in Hampstead Heath, amidst a thriving colony of political exiles who found a bond with one another, regardless of the schism within the Russian socialist movement. Chicherin, whose aristocratic family could trace its origins and name to an Italian courtier who had settled in Russia at the time of Tsar Ivan III, had worked in the archives of the tsarist foreign minister. He was something of a polymath, endowed with an encyclopaedic memory. A renaissance man, well versed in literature and culture, he was also a fine pianist and the author of a highly acclaimed book on Mozart's operas. He cut an eccentric and ascetic figure in London, leading a rather bohemian life. The conscience-stricken Chicherin had initially been a disciple of Tolstoy, before he joined the Russian revolutionary movement in exile, leaning towards Menshevism. This shortlived deviation did not deter Lenin from later appointing him commissar for foreign affairs. His signature would adorn the Brest-Litovsk and Rapallo agreements, the pillars of Soviet diplomacy.

Litvinov, who had an obscure Jewish background and did not entertain any intellectual pretensions, was later to be meticulous in his work in Narkomindel (the Soviet Foreign Ministry), fastidiously observing the rules and etiquette of diplomatic work, and almost dismissive of the ideological constraints imposed on him. Surprisingly, despite his conspicuous personal contempt for Chicherin, the two were able to work together harmoniously for almost a decade.

By the time they met in England, Litvinov, who was only eight years older than Maisky, had already gained a reputation as a seasoned revolutionary. It was therefore only natural for him to become Maisky's mentor, introducing him to the country, its political institutions, its culture and a wide circle of people. What most endeared Litvinov to Maisky was his strong character, as well as his ability to grasp the essentials of a question without getting bogged down in the details, and his penchant for irony.

The outbreak of the First World War, however, brought an estrangement between the two which was to mar their future working relationship. While Litvinov adopted Lenin's position and was in favour of militant defeatism, Maisky sided with the Menshevik's internationalist pacifist position, which sought an end to the war. For a while, Maisky even displayed great interest in the then all-encompassing popular ideas of the 'Middle Europe' movement, propagated by F. Neumann, which tried to merge the two most powerful waves of German history - the national-bourgeois wave and the socially oriented proletarian. It further sought to synthesize the precepts of Christianity with German idealism, humanism with class solidarity, and democracy. ${ }^{16}$ Maisky's ingrained pragmatism and humanistic outlook, further enhanced by his English experience, came to the fore as the First World War dragged on. He was particularly obsessed with the fate of Western civilization and the European intelligentsia, who were being slaughtered in great numbers on the front line, and wanted humanism to be placed before any party considerations. 'You see,' he responded to a rebuke from Julius Martov, the Menshevik leader, 


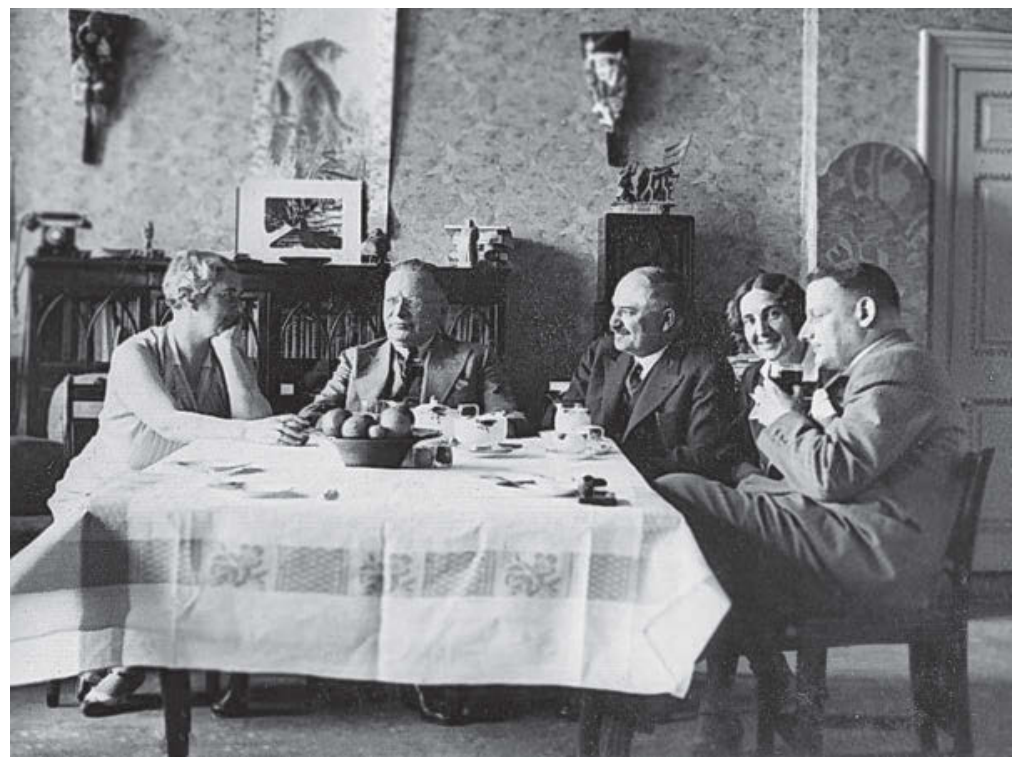

12. Ivy and Maksim Litvinov sipping tea with Ivan and Agniya at the Soviet embassy, 1935.

the longer the war drags on, the more a very serious danger appears before the belligerent nations: an enormous number of intellectuals - writers, artists, scholars, engineers, etc. - will die on the battlefields. The countries are exhausting their spiritual aristocracy, without which, whatever you say, no mental, social or political progress is possible ... Of course, any losses are difficult to bear: losses of peasants, losses of workers, etc.; but I still think that losses among the intelligentsia are, in relative terms, the hardest, because they are the most difficult to make good. The intelligentsia is a fruit that grows slowly, and it might need a whole generation before the depletion in its ranks caused by the war is even partly put right.

That's why I think that a period has now begun when nations, for their own self-preservation, will have to protect intellectuals the way they protect, for instance, skilled mechanics, chemists, trained armaments workers, etc. ${ }^{17}$

Although Maisky is at pains to demonstrate in his diary (and even more so in his autobiography) the kinship and warmth that characterized his relations with Litvinov a presentation that has led historians to pair the two - at times that relationship was troubled. Their temperaments were hardly compatible, and Litvinov did not shy away from rebuking Maisky, criticizing his essays on foreign affairs; on several occasions he even complained about him to Stalin. ${ }^{18}$ It was typical of Litvinov to keep people at arm's length, though much of this was a deep-seated disdain for the cosmopolitan intellectuals. 'Litvinov had no friends,' recalled Gustav Hilger, a veteran and well-informed counsellor at the German embassy in Moscow. 'There was one member of the kollegia of the Foreign Commissariat with whom I had established a relationship of mutual confidence. I asked 
him once how he got along with Litvinov, and received the significant answer "You don't get along with Litvinov; you only work with him - if you have no other choice."19

Moreover, Litvinov detested those diplomats (and Maisky was certainly one of them) who sought the limelight. 'Dignity', it was said of him, 'came natural to him ... Flattery and bootlicking were entirely foreign. Nor could he bear these traits in others. ${ }^{20}$ And yet they shared a common view of the international scene in the 1930s, and Litvinov did not shy away from supporting Maisky and even shielding him from the repressions which engulfed the ministry in 1938. ${ }^{21}$ Maisky was to continue to cultivate the special relationship which had been forged in exile. Congratulating Litvinov on his negotiations in Washington, which would lead in 1934 to American recognition of the Soviet Union, Maisky wrote: 'Perhaps it's because you and I are joined by a 20 -year acquaintance and by the years of emigration we shared in London that I always follow your work and your speeches on the Soviet and international arena with a very special interest and an emotion of an almost personal character ... Our long acquaintance gives me the right to tell you frankly things which, in other circumstances, could only seem out of place. ${ }^{22}$

Maisky's relations with Aleksandra M. Kollontay, the flamboyant and militant feminist and a future Soviet ambassador to Norway and then Sweden, at whose house he first met Litvinov, were entirely different. With her he maintained a warm personal friendship throughout his life. 'I find it interesting to be with Maisky,' Kollontay noted in her diary, 'because we don't only talk business. He is a lively man with eyes, mind and feelings open to perception of life in all its manifestations and in all fields. He isn't a boring, narrow-minded person who doesn't step beyond current business and issues. ${ }^{23}$

Shortly after the February revolution of 1917, which brought down the tsarist regime, Maisky returned to Russia and was asked by Aleksandr Kerensky to join the Provisional Government as the deputy minister of labour. His politics were fast veering to the right of the Menshevik Party. In the wake of the dissolution of the Constituent Assembly by the Bolsheviks, in January 1918, and the outbreak of the Civil War, Maisky failed to convince the Mensheviks to support the Samara-based Committee for the Reconvocation of the Assembly (Komuch) in its struggle against the Bolsheviks. His appeal to them was in keeping with his belief - a legacy of his European social-democratic experience - that staying neutral in the Civil War was 'contrary to human nature and logic', and that the Komuch government, composed of refugees from the Assembly, was a 'democratic counter-revolution'. Acting on his personal convictions, Maisky defied the party, and in July 1918 crossed the front line to join the forlorn Komuch government as its minister for labour. He thus emerged as the champion of the sole armed socialist insurgence against Bolshevism. ${ }^{24}$ This was a move that would haunt him for the rest of his life and would lead to an ignominious repentance, which was dismissed by the Mensheviks as 'memoirs of a renegade'. The 'newly baptized' convert was duly expelled from Menshevik ranks and admitted to his adopted church, branded with the eternal mark of Cain. ${ }^{25}$

When the White Admiral Kolchak seized control of the rebel government in 1919, persecuting the socialists, Maisky had to flee again, this time to Mongolia. His year in Mongolia, spent 'crossing Genghis Khan's former homeland on horseback and camel- 
back ... among the deserted mountains and steppes, far from the political struggle, the heated public atmosphere, the influence of party traditions and prejudices', made him reflect on the nature of the revolution - and on his own personal future. ${ }^{26}$

Maisky's earlier timid and procrastinating attempts in summer 1919 to break with the past and make it up with the Bolsheviks - undertaken at a time when their fate was still hanging in the balance - were regarded as inadequate contrition. ${ }^{27} \mathrm{~A}$ year later he wrote to People's Commissar for Education A.V. Lunacharsky, whom he had befriended during his years in exile:

I now see that the Mensheviks were virtuous but talentless pupils of the past, timid imitators of long-outlived models, thinking in old clichés and formulae from books, without that precious feel for life, feel for the epoch ... The Bolsheviks, on the other hand, excelled in boldness and originality, felt no particular piety towards the behests of the past or towards dogmatic incantations. They were flexible, practical and decisive ... they spoke a new word in the field of revolutionary creativity, they created new forms of state, of economic life, and of social relations ... which others lacked the boldness to realize. ${ }^{28}$

Throughout his life, and particularly during the dark days of the 'great terror', Maisky's earlier association with the Mensheviks, and particularly the role he played in the Civil War (something that was meticulously glossed over in his memoirs and writings), cast a huge shadow over his career and credibility in Moscow. The constructed narrative of his conversion to Bolshevism that he sent to Lunacharsky - atonement for his failure to recognize the Bolshevik Revolution as a legitimate socialist one - concealed the torment of soul-searching which the transition involved and which was never to be fully resolved.

Maisky's inner conflict was reflected in The Peaks (Vershiny), a four-act drama in verse which revealed the everlasting romantic nature of his thinking, deeply immersed as it was in the nineteenth-century universal humanist tradition of the Russian intelligentsia and coloured by utopian visions. The distinctive codex of the intelligentsia was the formation of a Russian intellectual, independent of his class origin. The title page of The Peaks bore an epigraph from Maisky's favourite poet, Heinrich Heine, in German with a Russian translation: 'We want to create the kingdom of heaven here, on earth!' Its theme was 'humanity's endless movement towards the glittering peaks of knowledge and freedom, which were visible and beautiful, but which could never be reached, because the movement was endless'. The extent to which Maisky genuinely repented and fully identified with the Bolsheviks (as he manifestly claimed to do in the first volume of his memoirs, written in dire circumstances in 1939-40) is hard to ascertain. In a selfreflective mood, Maisky related with empathy to Chicherin's account of his conversion to Bolshevism which seemed to be a mirror image of how he felt:

'Although I was once a Menshevik our ways have parted. The war has taught me a lot and now all my sympathies are on the side of the Russian Jacobins.' He hesitated for a moment and then added: 'I mean the Bolsheviks.' I cannot be certain that at the time of this conversation Georgii Vasilevich was a convinced Bolshevik. ${ }^{29}$ 


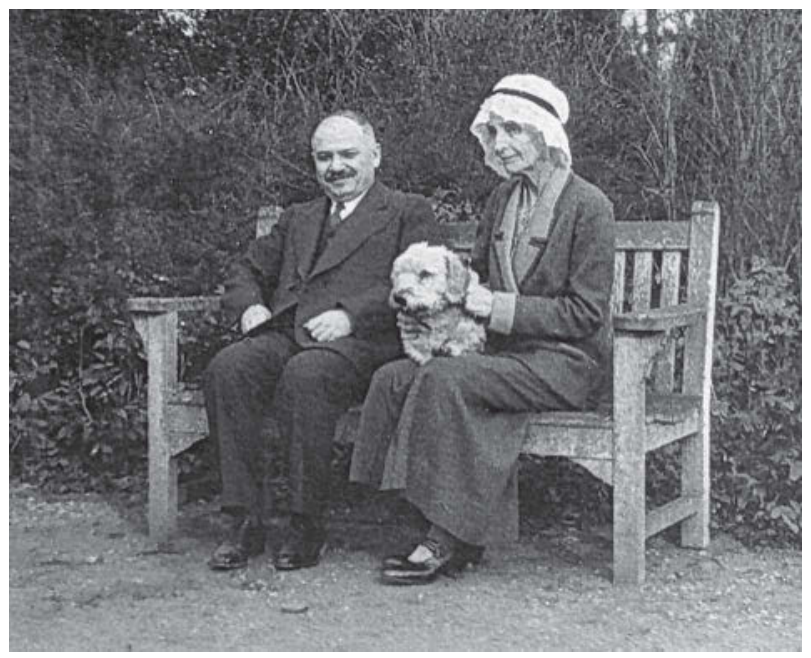

13. Maisky visiting his Fabian socialist idol and intimate friend Beatrice Webb at her countryside home.

Later on, in her diary, Beatrice Webb, one of Maisky's few trusted and intimate friends, painted a succinct and precise picture of Maisky's intellectual and political character:

Certainly Maisky is one of the most open minded of Marxists, and is fully aware of the misfits in Marxian terminology - scholastic and dogmatic. But then he has lived abroad among infidels and philistines and his mind has been perhaps slightly contaminated by the foreign sophistical agnostic outlook on the closed universe of the Moscow Marxians. ${ }^{30}$

Concerned with the 'earthly punishments' awaiting him in Moscow for his 'political sins', Maisky hoped to secure through Lunacharsky an amnesty for his past and a guarantee of safe passage as surety 'against arrest, search, conscription, etc., on the road'. Lunacharsky passed on The Peaks and the covering letter to Lenin, recommending rehabilitation and even admittance to the Bolshevik Party. The Politburo approved, though in guarded terms, suggesting that Maisky's expertise in economics should 'first be used in the provinces'. He was accordingly instructed to proceed to Omsk, where he eventually established the first Siberian State Plan (Gosplan). Meanwhile his repentance was published in Pravda. ${ }^{31}$

Maisky's ambitions, however, were intellectual rather than political. They led him at the first possible opportunity to Moscow, where he immediately established contact with Chicherin and Litvinov - 'for old times' sake', as he later recalled, ${ }^{32}$ but clearly in the hope of enhancing his credibility, which had been shattered by his association with the Mensheviks. ${ }^{33}$ He grudgingly accepted a proposal to become head of the press department of the People's Commissariat for Foreign Affairs (Narkomindel), regarding the position as merely a springboard to greater things. At the ministry he met Agniya 
Aleksandrovna Skipina, a strong-willed socialist activist, who was to become his third wife (a brief earlier marriage had produced a daughter, who went to live with her mother in St Petersburg and with whom Maisky, who had no further children, maintained sporadic contact; he had also had a short marriage of convenience to help a Russian stranded in London).

Hardly had he settled in his new post than Maisky quarrelled with Lev Karakhan, ${ }^{34}$ Chicherin's protégé, seeking his dismissal. Having failed to achieve his goal, he did succeed in steering Molotov, then the organizational secretary of the party's Central Committee, to send him to Petrograd, where he briefly acted as the deputy editor of Petrogradskaya Pravda. This interlude as second fiddle ended in harsh discord with the chief editor, who, as Maisky complained to Molotov, had 'taken care to make it impossible for [him] to work at the paper'. A brief spell as editor of the social and literary journal Zvezvda (The Star) came to a similar end in early 1925, following a squabble within the editorial board. On the whole, life in Leningrad did not agree with Maisky (or, more likely, with his young wife). He felt, as he explained to Molotov, like an 'outsider ... a second-class citizen'. In the relatively calm days of the New Economic Policy (NEP), Maisky could still comfortably manoeuvre his career, informing Molotov that he was 'seriously contemplating returning' to work in Narkomindel. ${ }^{35}$

Maisky's first steps in his Bolshevik career revealed an inflated self-esteem, marked by a sense of intellectual superiority and a stubbornness which did not endear him to his colleagues and superiors and often set him on a collision course with them. Although the survival instinct somewhat suppressed those traits during the oppressive 1930s, they would nonetheless keep resurfacing throughout his ambassadorship in London, particularly in his encounters with British officials.

Back in Moscow, Maisky's fraternal relations with Litvinov, who was gradually taking over from Chicherin as the strong man in Narkomindel, proved propitious. In 1925 he was appointed counsellor at the Soviet embassy in London, a position which he clearly cherished. As he wrote to his mother, he and his wife Agniya:

have taken a small house where no one else lives, we have a maid and we look after our own household ... Agniya is learning singing and English and she's starting to chatter a little in English. Our house is in one of the best London suburbs, next to the botanical garden, the air is beautiful, but it's just a shame we don't get more chance to enjoy it. ${ }^{36}$

But his stay in London was again marred by poor relations with his superiors at the embassy. Maisky opted to go back to Moscow, but within a year was persuaded by Litvinov to return to the embassy. Those were turbulent years in Anglo-Soviet relations, following the 'Zinoviev letter' affair of 1924 and the 'Russian gold' contribution to the miners during the General Strike of 1926. There was a fear in Moscow of a rupture in relations, and perhaps even of renewed military intervention. Matters were further exacerbated by the premature death of Leonid Krasin, the Soviet ambassador in London. As one of the few revolutionaries fluent in English and well versed in British affairs, Maisky found his services required. It is rarely recognized that, with no ambassador in London, as counsellor Maisky actually functioned as the de facto polpred. 'In the old days,' he 
boasted in a letter to his father, 'a counsellor would have figured very high on the "table of ranks". Nowadays, the table of ranks has lost any significance for us; however, I can assure you that the work of a counsellor in a place like London is highly interesting and important ... London today is the powerful centre of world politics which can only be compared to Moscow. ${ }^{\prime 37}$ His enforced departure from England, following the severance of diplomatic relations in May 1927, left Maisky, as he confided to C.P. Scott, the proRussian editor of the Manchester Guardian, with 'a feeling very much akin to personal grief'. His years in exile in London and the experience in the embassy had led him 'to understand and respect British culture, which, although so unlike Russian Culture, contains much which is both valuable and great'. ${ }^{38}$

After six weeks of rest and treatment 'on doctors' orders' at the Kislovodsk sanatorium in the Caucasus, Maisky was appointed counsellor at the Soviet embassy in Tokyo, where he spent the next two years. For a while, the appointment suited him well. 'I arrived in Tokyo at the end of October,' he wrote to H.G. Wells, 'and at the present time look around with the greatest possible interest studying this most extraordinary country, which some twenty years ago gave you a good deal of inspiration to write "Modern Utopia".' Writing to the left-wing publicist Henry Brailsford, Maisky hailed Japan as a 'unique country ... combining in some extraordinary manner Oriental Mediaeval with the most modern Americanism ... Add to this beauty of Nature, "Eigentumlichkeit" of people, of habits and customs ... No wonder that so far I had no reasons to complain that our Foreign Office has sent me to this country. ${ }^{39}$

Always indignant when placed in a subordinate position, Maisky was glad to see the Soviet ambassador transferred to Paris, as this put him (temporarily at least) in charge of the embassy. His experience in Japan helped shape his views on diplomacy, and particularly the belief that diplomats should be fully immersed in the culture and language of the country they were posted to. ${ }^{40}$ As a way of introducing the Russian

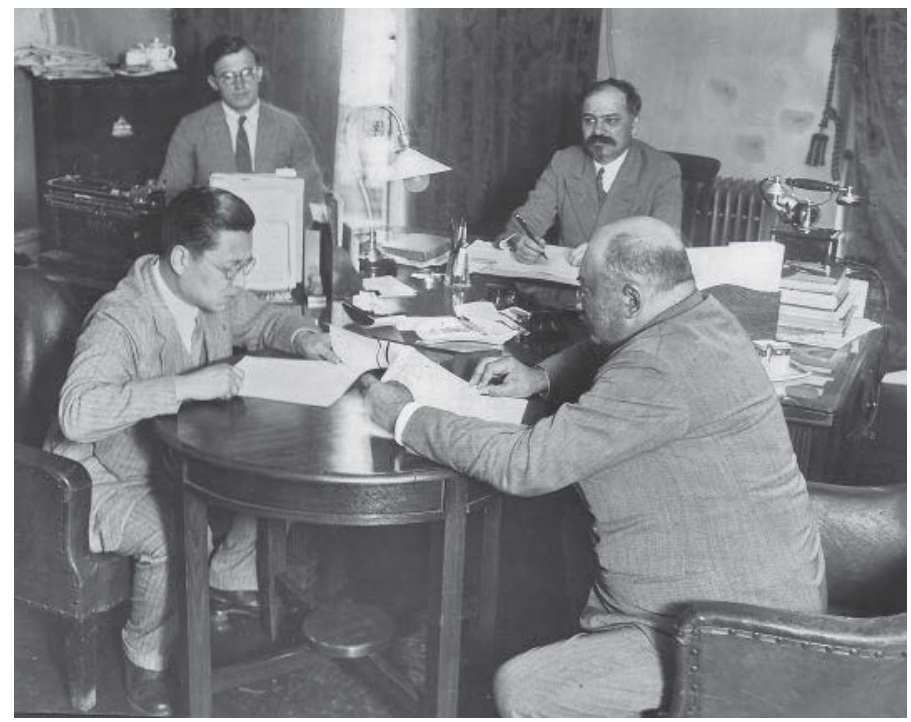

14. Apprenticeship at the Tokyo embassy. 
public to Japanese culture, he organized an extensive visit by the leading Kabuki theatre to Russia, which encountered resistance within Japanese conservative circles. Indeed, during the troupe's first performance back in Japan, following its triumphant tour of Russia, hired thugs released 'live snakes under chairs all around the hall, just before it began. During the show, the snakes began hissing and crawling amidst the audience. A fearful panic broke out. Men snarled, women shrieked, children cried, the curtain had to be lowered and the performance was interrupted. ${ }^{\prime 41}$

Several months later, once again in a subordinate position far from Moscow and Europe, and on the fringes of diplomacy, Maisky was feeling depressed. Moreover, as would be manifested time and again, he was easily led by the whims of his wife, who, he confided to a friend, was 'feeling herself insignificant: primarily unemployed'. ${ }^{42}$ The embassy had become a hotbed of intrigue and calumny. Agniya and the wife of the trade representative were 'at daggers drawn' as to who should be the 'First Lady' at state functions. This antagonism between the two, which led to a flurry of correspondence between the embassy and Narkomindel, was not settled in Agniya's favour, and split the Russian colony into factions. ${ }^{43}$ Barely a year into his mission, Maisky complained to Chicherin that living in Japan was 'generally dull and wearisome: there is little political work (not enough for two), and any even slightly important question is dealt with in Moscow'. By now, however, Chicherin was ravaged by severe diabetes and was losing his grip on Narkomindel. ${ }^{44}$

Maisky therefore turned to Litvinov with an explicit demand for a prompt transfer, motivated by the Ménière's disease which had troubled his wife since their sojourn in London and which, he claimed, had got worse in Tokyo, leaving her deaf in one ear. He further complained about the havoc which the weather in Tokyo was playing with his own health. Though it was up to the Collegium of Narkomindel to decide on his future appointment, Maisky did not fight shy of stating his own preference for spending a year or two in Moscow (though he was quick to add that he had 'no objection whatsoever to returning to the West'). Litvinov responded favourably, proposing an ambassadorial role in Kovno, which he presented as the fourth most important post after Berlin, Paris and Warsaw. He was, however, also prepared to discuss alternatives if the offer did not appeal to Maisky. It is remarkable that, at the turn of the decade, it was still possible for a Soviet diplomat to dictate his own terms of employment.

It was with great relief that Maisky received the news of the Politburo's decision to withdraw him from Tokyo in January 1929. 'Your attitude,' he wrote to Litvinov in his now familiar supercilious yet cunning way, 'inevitably invigorates my "Narkomindel patriotism" and wish to work in this environment. ${ }^{45}$ On 4 April he was assigned to Narkomindel's press department, but within a week the decision was taken to appoint him as minister plenipotentiary to Helsinki, where he spent the next three years. His stay there culminated in the successful conclusion of the Helsinki Agreement on nonaggression in $1932 .{ }^{46}$ Though a weighty post, even Helsinki was far from attractive to Maisky, who clearly aspired to a much more prestigious and challenging position in Central or Western Europe. 'The Russophobia and Sovietophobia here,' he lamented to H.G. Wells, 'are supreme. It is a sort of a general delirium's attack.' For the moment, however, he tried to maintain 'a cheerful and a good fighting spirit' ${ }^{47}$

Service in London clearly continued to attract Maisky. Even after his expulsion from England in 1927, he had remained attuned to the British political scene. He 
was thoroughly briefed by Brailsford, H.G. Wells and others about the prospects of the 1929 general election, which could signal the resumption of diplomatic relations - if not indeed his return to London. Those hopes, however, were dashed after the elections, when Ramsay MacDonald's foreign secretary, Arthur Henderson, made the re-establishment of relations with the Soviet Union conditional on a settlement of tsarist debts. MacDonald, so Maisky learned from his sources in London, 'whether by accident or design, tumbled right into the Tory trap, and repeated his old declaration about the identity of the Soviet Government with the Komintern [sic]'. The three months he spent in Moscow before taking up his post in Helsinki convinced Maisky that, despite the critical domestic situation, the Soviet government was 'at present not at all in the mood to pay that exorbitant price'.$^{48}$ His main thrust, therefore, was now directed towards Central Europe.

Maisky's prospects of advancement brightened when Litvinov replaced the ailing Chicherin as commissar for foreign affairs in July 1930. Maisky was quick off the mark in congratulating Litvinov, though in a somewhat condescending way, reminiscing about their shared dreams and hopes while in exile in London, and the endless evenings spent together discussing world affairs in a 'murky, sooty flat at 72 Oakley Square'. This was only a prelude to repeated requests for a transfer from Helsinki, a 'small political nowhereville ... and a very dull one', hardly a place where 'an active and energetic polpred can remain for long'. Maisky again tried to dictate his own terms, this time by setting the beginning of the year as the deadline for his transfer - even to the extent of apparently being prepared to forsake his position at Narkomindel. 'My intention to seriously commit myself to a long-term diplomatic work, of which I wrote to you a few years ago from London, has not weakened in the intervening years but rather intensified,' he informed Litvinov, 'so that I should be reluctant to leave Narkomindel. Of course, if any concrete prospects for transfer do turn up, I would ask you first to consult with me. ${ }^{\prime 49}$

By now Stalin's firm grip on the commissariat was restricting Litvinov's room for manoeuvre. Neither Maisky's personal pleading, while on vacation in Moscow at the start of 1931, nor a later appeal, again harping on Agniya's failing health (which he claimed could only be treated in Vienna), seemed to move an increasingly disgruntled Litvinov. 'As you ought to know,' he reminded Maisky, 'this issue is not decided by me alone, but by other authorities who are least of all inclined to take account of personal considerations. ${ }^{50}$ Little deterred, Maisky went on pushing forward his own plan, alas in vain: 'Are you certain that working in Vienna would condemn me to diplomatic passivity? Is it really impossible to work on Hungary and the Balkans from Vienna? Won't it be possible to make Vienna our immediate link in dealings with the League of Nations, etc.? ${ }^{\prime 51}$

In the absence of any response, Maisky confined himself to heaping praise on Litvinov, while vigilantly awaiting new opportunities: 'I have no affairs for you today, I just wanted to congratulate you even at a distance on your recent successes in Geneva ... The diplomats here are also showing a heightened interest in your personality, and talk quite often of your Geneva successes. ${ }^{52}$

Resigned to a prolonged stay in Helsinki, Maisky was dumbfounded when the unexpected news of his appointment as plenipotentiary to London was conveyed to him by telephone on 3 September 1932. When, a month or so earlier, the Maiskys had 
visited Kollontay in Stockholm and candidly confided in her, the appointment to the United Kingdom was certainly not on the cards. 'After a minor post as plenipotentiary to Finland,' an amazed Kollontay commented in her diary, 'suddenly London and at such a troublesome period. ${ }^{153}$ Many diplomats were shocked by his appointment, remembering his dubious past in the Samara government during the Civil War. The decision was obviously made in great haste and reflected a change in the orientation of Soviet foreign policy. Litvinov had succeeded in convincing Stalin that Maisky's familiarity with England - and particularly his ability to communicate and engage people in conversation - was vital. Stalin saw in it 'some sort of an experiment'. ${ }^{54}$ Within two days, Litvinov sought an agrément for Maisky. The feeble excuses he offered for Ambassador Sokolnikov's abrupt withdrawal were the latter's desire 'to assume work in the Soviet Union' and 'the London climate which does not suit him'. As Maisky's name did not appear on the Home Office's 'black list' of Soviet diplomats who were engaged in subversive activities during the crisis of $1927,{ }^{55}$ the Foreign Office grudgingly agreed that there was 'nothing in M. Maisky's record that would make him persona non grata to H.M.G.'. The more so as his record in Finland was 'not too bad'. ${ }^{56}$

The appointment, perfectly tailored to Maisky's temperament and ambitions, was perceived by him as recognition of his talents and status, placing him as a lead actor at the front of the stage. 'London,' he wrote to his father, 'is a world centre. The other world centre is Moscow. I have to work at the intersection of these two world systems, so it's no surprise that all my time and energy goes on dealing with the many problems that arise from the simultaneous existence of the Soviet and capitalist worlds. ${ }^{157}$ To Whitehall, the appointment of Maisky signalled the Soviet Union's wish to shake off its revolutionary image in Britain by adopting a pragmatic and gradualist course towards socialism. Sokolnikov was evidently ill-suited to the position. Like Maisky, he was the son of a Jewish doctor in the provinces. He had signed the Brest-Litovsk peace agreement with Germany in 1918 and excelled as a minister of finance during NEP. However, his association in 1924 with the 'new opposition' of Kamenev and Zinoviev, who were calling for the removal of Stalin as general secretary of the party, led to his exile as ambassador to London in 1929-32. As long as relations with Britain remained on a low flame, Sokolnikov could be safely kept in England. However, his isolation clearly took its toll and undermined his ability to act in the quickly changing circumstances which now rendered relations with Britain vital to Russian national interests. His English was poor, and even the benevolent Beatrice Webb found him 'studious and ascetic - a veritable puritan - non smoker, did not drink his wine ... with a naive faith in communism as the last word of science'. He spent most of his leisure time in the British Museum reading room. He was, she thought, 'a strange member of the diplomatic circle ... a nonentity'.

Maisky, on the other hand, was chosen by Litvinov precisely because of his engaging personality. When Sir Esmond Ovey, the British ambassador in Moscow, met Maisky for the first time, he found him 'affable and talkative ... a much better "mixer" than his predecessor'. Mentioning those qualities to Litvinov drew an immediate response: 'That is why I appointed him!'58 In Stockholm, Kollontay attributed his appointment to the growing fear in Moscow that the deteriorating relations might again, as in 1927 , lead to their severance. The fact that she had been inundated by telegrams from Litvinov, seeking any possible piece of information about British politics, implied that the ambassador in London was no longer trusted. 


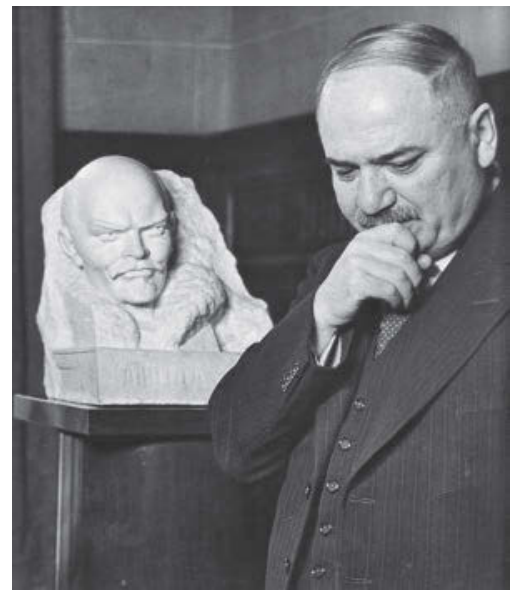

15. Maisky trying hard to become a Bolshevik.

The timing of the appointment was propitious, as Stalin's desire to remove Sokolnikov from his post coincided with Litvinov's wish to shift his diplomatic efforts from Berlin to London and to break through the wall of Conservative hostility. Maisky's success in concluding a non-aggression pact with Finland and his constant lobbying surely played their part, the more so as Litvinov was apprised of his wide range of acquaintances in England, his command of the language and his familiarity with the country. ${ }^{59}$ Sokolnikov's outspoken militancy, observed Beatrice Webb after first meeting Maisky, was replaced by 'a more accomplished diplomat and less ardent Communist'. Indeed, Maisky's Menshevik past did not go unnoticed in the Foreign Office, and nor did the circumstances which led to his admittance 'to the Bolshevik fold' only after he had made 'a formal recantation'. Soviet communism, as Maisky confided to Beatrice Webb, was 'in the making'. He brushed off the 'fanatical metaphysics' (a substitute term for 'ideology') and the repressions as an inevitable transition stage. He believed in 'the new civilisation' established in the Soviet Union as a 'next step' in human progress, but not the 'final one', without being 'fanatical'. ${ }^{60}$ The human race, he told Webb, would 'go on marching to ever increasing knowledge, love and beauty'. He indulged in utopian dreams about a time when the individual would 'be absorbed in the pursuit of the interests of the whole community. Through the advance of knowledge man would conquer this planet and then he would proceed to conquer Venus!'61

Likewise, when it was still relatively safe to express views freely, Maisky wrote to Bernard Shaw that he did not regard the Soviet Union under Stalin to be the ultimate socialist achievement. Confronted by Shaw with a biting critic of the 1936 constitution, Maisky recalled that it was a 'Constitution for the Soviet Union in the present stage of its struggle towards the Communist society' - 'the socialist stage'. Playing with the Webbs the 'dangerous game' of what would happen 'after the disappearance of Stalin', Maisky dismissed the idea that he would be replaced by another 'idolized' leader. An idol leader would be 'dispensed with and a completely free communist democracy established' ${ }^{62}$ 
On 5 September 1932, Maisky was informed by Litvinov that he had 'carried the decision on [his] appointment with the instantsiya [Stalin], so it only needs to be passed by the Central Executive Committee, which will be done upon receiving the agrément'. Maisky, who had already agreed to give up his summer vacation, was encouraged to proceed to Moscow for a week of briefing before being whisked off to London. The instructions he received, Litvinov assured him, were not a reflection of his 'own personal views, but the directives of our higher authorities'. ${ }^{63}$ Maisky was made privy to the apprehension in the Kremlin that Weimar Germany was on its 'last legs' and that Hitler's imminent seizure of power was bound to introduce chaos on the international scene and threaten peace, which was indispensable for the domestic, economic and political transformation of the Soviet Union. Litvinov had already commented with irony that it was hardly possible to make five-year plans in international politics. The advance of Nazism therefore required a dramatic volte-face in relations with Great Britain, hitherto considered to be the spearhead in the crusade against the Russian Revolution. Foreign policy, unlike domestic politics, had become largely reactive, flexing according to shifting challenges. ${ }^{64}$

The harsh reality dictated a shift from attempts to mobilize socialist solidarity and support for the Russian Revolution among Labour circles to courting the Conservatives, who were, as Litvinov never tired of stressing, 'the real bosses in Britain!'65 Within days, Maisky returned to Litvinov with a working plan which would characterize his unconventional diplomacy, particularly his recourse to the press and to personal diplomacy, aimed at 'extending as widely as possible the series of visits which diplomatic etiquette imposes on a newly appointed Ambassador, and in doing so to include not only the narrow circle of persons connected with the Foreign Office but also a number of members of the Government, prominent politicians, people of the City and representatives of the cultural world' ${ }^{66}$

Working with the Conservatives was particularly challenging, heightening the ingrained tension which characterized the work of Soviet diplomats. While in Helsinki, Maisky had already been grappling with the nature of a revolutionary diplomacy. He had sought guidance from Brailsford: 'Do you know of any work describing diplomatic activities/diplomatic relations, position of revolutionary diplomats at foreign courts and governments, etc. of English, American (1776) and French (1789) revolutions? Do not you know perhaps some interesting memoirs of such revolutionary diplomats?' He was still preoccupied with the subject in 1933, trying to find out, as he confided to Beatrice Webb, 'how the revolutionary diplomats were received and how they behaved' ${ }^{67}$ The dilemma for the often ostracized Bolshevik diplomat, allured by the charm of the bourgeoisie, was how to adopt a conformist manner and way of life and to fraternize (if not identify) with the 'enemy', while keeping the revolutionary zeal and ethos alive. This became particularly testing after the diplomatic setbacks inflicted on the Russians in 1927, a consequence of their involvement in the 1926 General Strike, which resulted in the collapse of the 'united front' tactics, deprived Soviet ambassadors of the cushion of Labour support and threw them into the Conservative lion's den. This dichotomy haunted Maisky throughout his long diplomatic career, and he had only a modicum of success in coping with it. Considering his Menshevik and 'counter-revolutionary' past, he was particularly susceptible to accusations of betrayal, which he fervently tried to 
wave away. When an article in Pravda spelled out the problem, Maisky was quick to exonerate himself in a long letter, implying his full awareness of the problem:

Among the people we have working abroad there is a constant internal struggle between two elements: the healthy revolutionary and proletarian element, which can give a true assessment of 'protocol', and a more sickly, opportunist element, comparatively easily subjected to the influence of the bourgeois surroundings ... The struggle between these two elements follows the rule that 'now one, now the other is driven to one side'. In particular, there is a danger that the supporters of 'protocol' might gain a certain advantage ... It would be very important if you would continue not to forget our 'abroad' and from time to time to publicize questions of the life of Soviet diplomacy outside the USSR. That would be a strong support for those elements among our overseas workers who consider 'protocol' merely a necessary evil and who therefore try to reduce all bourgeois conventionalities to the absolutely necessary minimum. For I myself have heard more than once how in doubtful cases, where it was unclear where exactly the unavoidable minimum lay, Soviet diplomats have said 'Better too much than not enough', 'You don't spoil the gruel with butter', etc. ${ }^{68}$

Similar pangs of conscience were expressed in Maisky's personal letter to Chicherin, congratulating him on ten years at the helm of Narkomindel:

You were faced with a very difficult task: to create a completely new type of foreign minister ... That task was far harder than creating, say, a new type

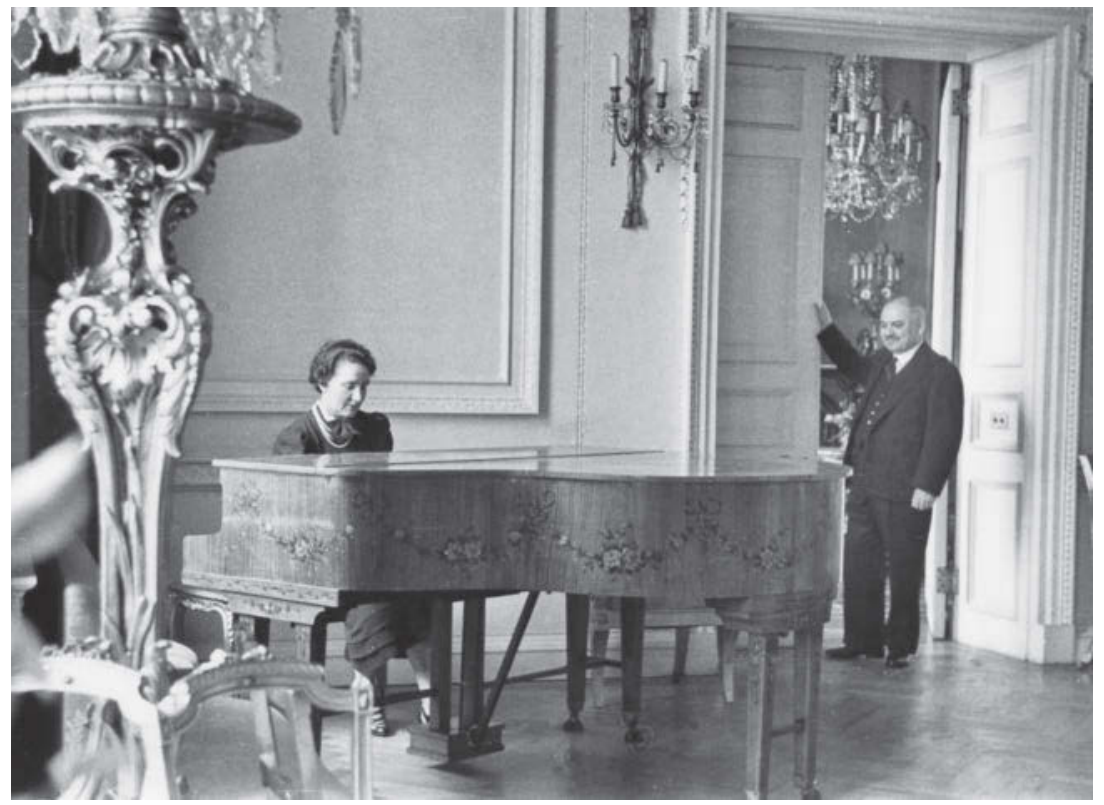

16. The alluring bourgeois environment at the embassy. 


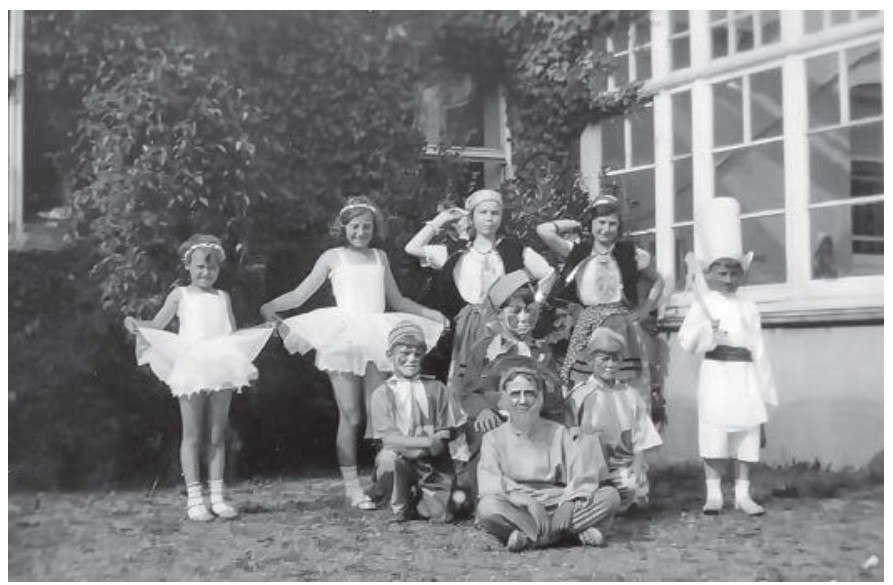

17. Ballet for the young: the vie quotidienne for the children of the embassy staff.

of finance minister or a new type of agriculture minister, because by the nature of your work you have always had to tread the fine line that divides us from the bourgeois world. You had a devilishly difficult position. ${ }^{69}$

Discomfort with the diplomatic role, if not feelings of guilt, continued to obsess Maisky, who was always eager to vindicate his position. In a letter to Litvinov congratulating him on his appointment as commissar for foreign affairs, he wrote:

Do you remember, Maksim Maksimovich, how in summer 1913, when you were secretary to the Herzen Circle and I was travelling from London to Germany, you were the initiator of a 'farewell luncheon' for me which took place in the company of a number of comrades at the Communist Club in Charlotte Street? Well, it seems that it was then that we started to learn 'diplomatic etiquette'!?0

And yet, it is most telling that Maisky preferred to be known in Britain (and indeed signed his letters) as Jean - the French variant of John, or the Polish Jan, as he was named by his father in his youth - rather than the archetypical Russian rendition of Ivan.

The dichotomy rendered Soviet diplomats particularly vulnerable to accusations of counter-revolutionary deviation. Surprisingly, during the purges only a few prominent diplomats defected while serving abroad. It has been suggested that the main reason for the paucity of defections, especially at the peak of the purges, was the stringent regime of prohibitive measures followed by the People's Commissariat for Internal Affairs (NKVD). ${ }^{71}$ It seems, however, that the reason why defection was not a viable option for most diplomats had more to do with their commitment to and affinity with both the regime and the country. They were engaged, as is attested by Maisky's diary, in a continuous self-searching process, seeking to successfully resist the seductive 'devil', while genuinely believing that those recalled and tried had betrayed the revolution. Maisky was alarmed by each case of deviation, defection or purge of a diplomat, even if 
he was only remotely associated with the person involved: he was always keen to prove that he had no connection, and consistently asserted his allegiance to the revolution. He was shattered by the early defection, in 1929, of Grigorii Besedovsky, the acting ambassador in Paris. In self-defence, Maisky hastened to reprimand Narkomindel for its failure to detect obvious early signals from Paris. At the same time, he advocated harsh measures, including 'the purge of overseas workers'. 'When will it happen, and in what forms?' he probed Litvinov. In a follow-up letter, he expressed the view that the Soviet Union was going through a critical stage in its development, when various 'unreliable, narrow-minded, careerist elements which have hung on to the party should depart from us with or without scandals. Not only abroad, but also in the USSR.' He was even going to suggest pre-emptive steps, which, he wrote to Litvinov, 'were better discussed in person than put in writing'. At the turn of the decade, with Stalin not yet quite firmly in the saddle, 'purges' - unlike the repressions which came in their wake - were embedded in the revolutionary culture. ${ }^{72}$ 